\title{
Mineralization, Mineralogy and Geochemistry of Saheb Fe-Cu Deposit of Saqqez (Kurdestan), NW Iran
}

\author{
Zahra Zandi' ${ }^{1}$, Alireza Jafari Rad ${ }^{1 *}$, Arash Gourabjeripour ${ }^{2}$, Mohammad Lotfi ${ }^{3}$ \\ ${ }^{1}$ Department of Geology, Science and Research Branch, Islamic Azad University, Tehran, Iran \\ ${ }^{2}$ Department of Geology, Myianeh Branch, Islamic Azad University, Myianeh, Iran \\ ${ }^{3}$ Department of Geology, North Tehran Branch, Islamic Azad University, Tehran, Iran \\ Email: *alirad@yahoo.com
}

How to cite this paper: Zandi, Z., Rad, A.J., Gourabjeripour, A. and Lotfi, M. (2018) Mineralization, Mineralogy and Geochemistry of Saheb Fe-Cu Deposit of Saqqez (Kurdestan), NW Iran. Open Journal of Geology, 8, 514-528.

https://doi.org/10.4236/ojg.2018.85031

Received: December 19, 2016 Accepted: December 28, 2016

Published: May 31, 2018

Copyright $\odot 2018$ by authors and Scientific Research Publishing Inc. This work is licensed under the Creative Commons Attribution International License (CC BY 4.0).

http://creativecommons.org/licenses/by/4.0/

\begin{abstract}
The Saheb Fe-Cu skarn deposit is located in the Sanandaj-Sirjan metamorphic belt, SE Saqqez, western Iran and has been formed along the contact between the Oligo-Miocene aged Saheb granitoid and the Permian aged impure calcareous rocks and includes endoskarn and exoskarn. Exoskarn is widely developed and includes garnet and epidote skarn zones. The majority of mineralized zones are concentrated in garnet skarn. The relatively oxidizing mineralogical assemblage of the Saheb skarn includes garnet (andradite-grossular), pyroxene (diopside-hedenbergite), magnetite and hematite. Magnetite is the main and abundant ore mineral throughout the ore deposit. Based on field evidences and microscopic studies of skarn zone samples, two stages of prograde and retrograde alteration are distinguishable. According to the results of sample analysis of Saheb skarn intrusive body by XRF and ICP-MS techniques, the combination of this body is chiefly granite to granodiorite-diorite and belongs to the I-type granitoids, metaluminous and K-rich calc-alkaline series. The Saheb granitoid is related to the VAG (Volcanic Arc Granite) tectonic setting.
\end{abstract}

\section{Keywords}

Iran, Saqqez, Saheb Deposit, Iron Skarn, Metasomatism, Magnetite

\section{Introduction}

There are many iron skarns in Iran. Some economically important well-known iron skarn deposits in Iran are as: Sangan [1] Gelali, Baba Ali, Khosro Abad and Shahrak [2] and Astamal [3] [4]. According to this, Saheb Fe-Cu skarn deposit is 
well-known, too and located in the city of Saqqez (Kurdestan province), North-West Iran and coordinated $34^{\circ} 46^{\prime}$ to $35^{\circ} 46^{\prime}$ east longitude and $36^{\circ} 16^{\prime}$ to $36^{\circ} 17^{\prime}$ north latitude (part of Sanandaj-Sirjan zone is enclosed). Sanandaj-Sirjan zone is one of the most active structural zones of Iran and may be incomplete name of the quietest areas of the institution. This zone is mainly metamorphic complex and intrusive granitoid rocks [5] and different types of mineralization have been observed (Figure 1), including several iron deposits for example: Gol-Gohar, Hame Kasi, Gelali and Baba Ali, Kalat Nasser, Ahangaran and Zafar Abad can be noted [6]. The northwest Iran has been interest to geologists and explorers because of the well developed alteration zones and high prospectivity for mineralization. The intrusive rocks in this area are high potassium calk-alkaline felsic rocks [5]. These rocks occur in the great belts which commonly extend for hundreds or even thousands of miles as individual bodies. One of the intrusive rocks is located in Saheb area and evidences of old mining operations are not seen. Volcanic activity, numerous intrusion associated hydrothermal fluids have led to formation of a wide variety of deposits. According to [7] iron deposits in Sanandaj-Sijan north and South is skarn and in the mid is, sedimentary-volcanic type.

In this research, we have tried to investigate the effects of mineral extraction, mineralogy and geochemical characteristics of the owner's store by using field evidences, laboratory and using the results of analysis of samples taken from the mineralization area, mineralogy and geochemical characteristics of the reservoir. Accordingly, after introducing the geology of the region and its various units, we will look at the characteristics.

\section{Geology}

The area in the southeastern city of Saqqez, in Kurdistan province, NW of Iran, and from the structural perspective is placed in the zone of Sanandaj-Sirjan. An

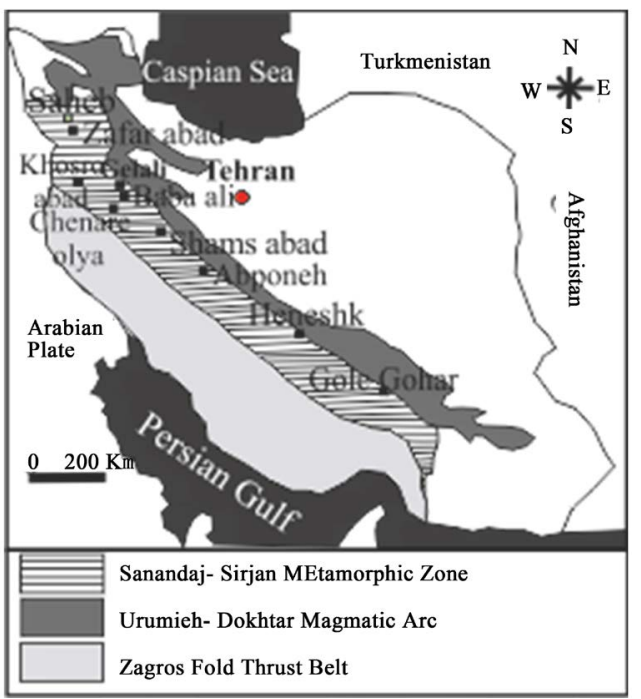

Figure 1. Distribution of mineral deposits in Sanandaj-Sirjan zone [10]. 
area is $2 \mathrm{Km}^{2}$ and is located in a part of the Soltan Mountain. This mountain is in the southern Chagharlu (Chapan) villages and about $16 \mathrm{~km}$ of north East of Saheb is located. Based on the map (Figure 2) geological units in this area includes Permian carbonate units, alteration and skarn units, granitoid body. The rows of limestone carbonate units include moderate to thick gray layer. The unit is free of any fossil and only based on the stratigraphy, age of this unit, Upper Paleozoic (Permian) has been reported [8]. Outcrops are limited to a small tab located in the eastern part of the study area. The lower contact is Cretaceous rocks units with carbonate units as fault and upper contact is mostly unknown, and it seems that the slope is continuous. The slope of this layer on the effects of change and tectonic pressure is variable and often steep and is near vertical ( 80 to 90 degrees). In addition, the tectonic and metamorphic processes have created altration and recrystallization of the carbonate units and marble is formed in parts of it [9]. Skarn unit is, including: limestone and dolomite that in addition to regional metamorphism, also have to bear contact metamorphism and therefore converted to skarn [8] [9].

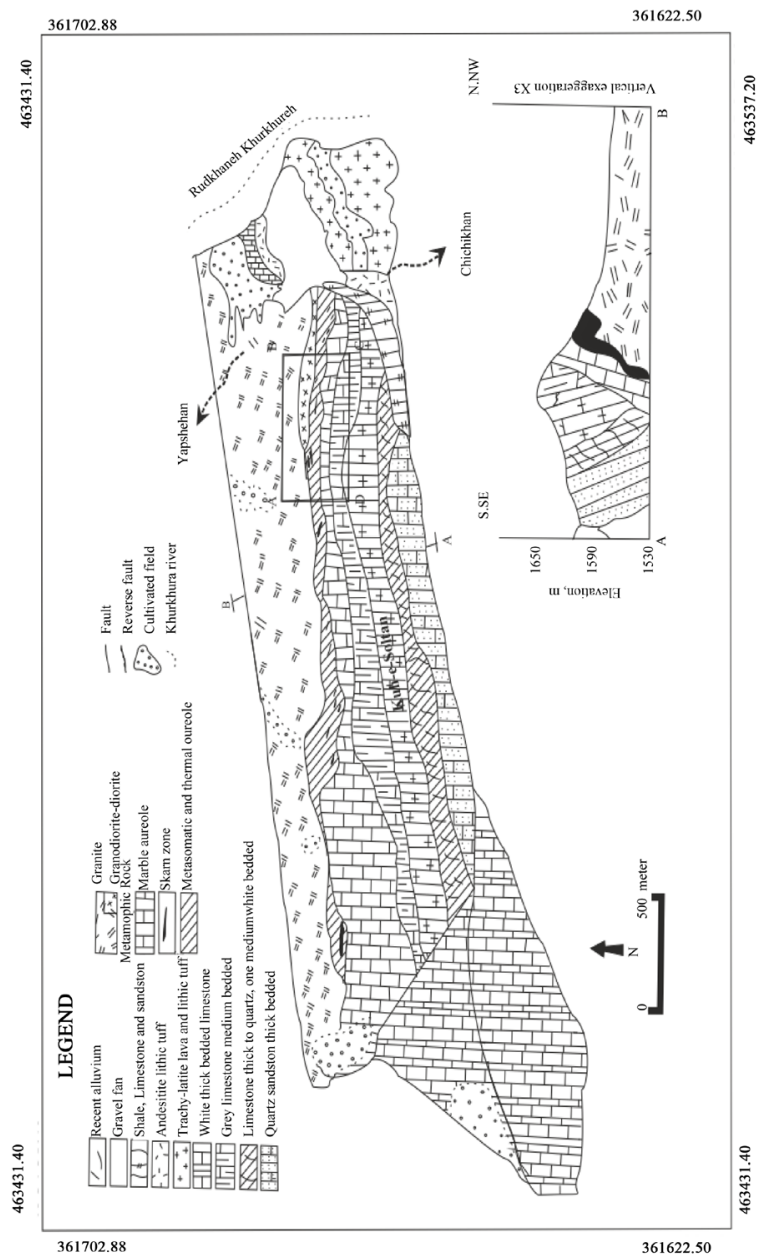

(a)

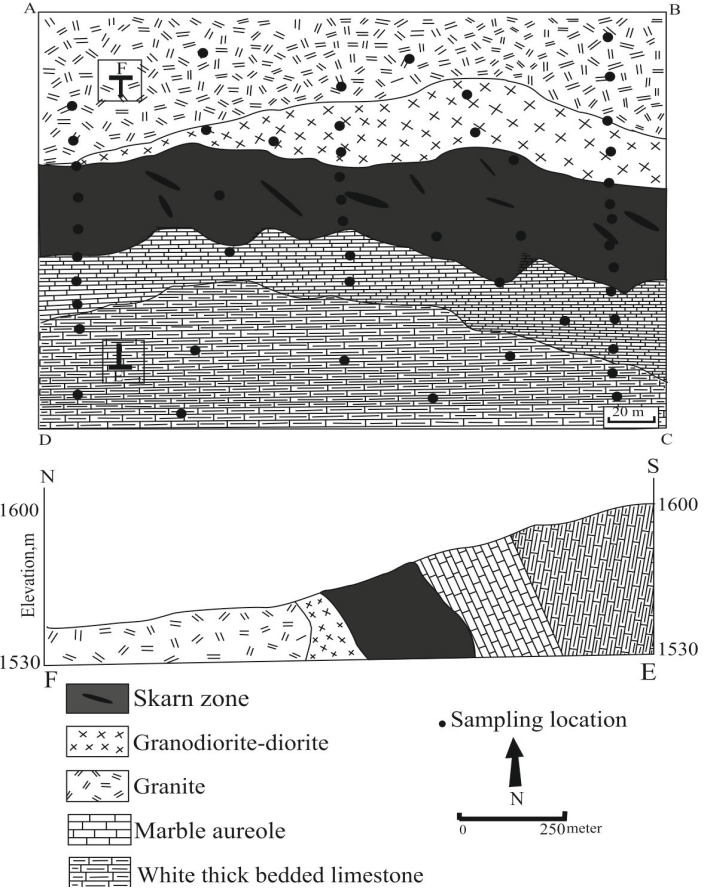

(b)

Figure 2. (a) Geological Map of the region from the map 1:5000 Saheb; (b) Samples location in section of this map [11]. 


\subsection{Geology of Skarn Zone}

Skarn zone is in the Permian dolomitic rocks and well tolerated transformation (recrystallization and marble latest). The thickness of this zone varies from 50 to 100 meters. Skarn is divided into two parts: Endo and exo skarn. In parts of zones of hydrothermal source has greater distance, almost none anhydrous calc-silicate minerals is formed in the marble zone and epidote and chlorite minerals only in a small amount is formed. But in parts of the thickness of the zones and the distance from the heat source is low, anhydrous calc-silicate minerals were formed [9] Changes in the thickness of this zone is due to changes in lithology and density of joints and cracks in the host rock and in the parts pelitic sediments were present, hornfels formed. Hornfels with characteristics such as green, microcrystal and high density that adds rock resistance to weathering of in the desert can be identified. This rocks form in effect contact metamorphic carbonate rocks with peletic rocks mostly due to high resistance and are very limited in the region, mineralization does not exist in them [9].

\subsubsection{Endoskarn}

This section of scorn zone is very limited ( 0.2 to 2 meters), texture of the original rocks has been preserved and only some secondary calc-silicate minerals such as epidote and chlorite are added to it. This expansion is under the control of joints density and fractures in intrusive igneous rock and in places where open space is enough to provide a fluid motion; this zone also has further spread [9].

\subsubsection{Exoskarn}

From a macroscopic point of view exoskarn is mostly brown, but on the part of the zone due to increased amounts of epidote, amphibole (tremolite-actinolite) and chlorite, is green color. These two colors represent two part: garnet skarn (on the contacts of the intrusion) and epidote -skarn (on the contacts with marble [9].Spread garnet skarn zone is more than epidote skarn. In this series, Garnet-skarn zone with considerable thickness to be allocated most of the metasomatic alteration. Mineralization of Magnetite predominantly and hematite partial, with copper carbonates (malachite) accompanied of exoskarn. Mineralization is often mass and lens form and in a lesser degree can be seen as veins and veinlets [9].

\subsection{Acidic Intrusion of Region}

Saheb intrusive body, in a hand specimen is pale pink and bright color is seen in the general case. Based on microscopic studies of plagioclase, alkali feldspar, amphibole, quartz and biotite are main minerals of this igneous rocks and on the basis of geochemical classification intrusive rocks, have ranging from granite to granodiorite-diorite [9] [12]. According to geophysical studies carried out and dimensions of harvest network, the overall trend of igneous formations is east-west direction and is designated for local body [9]. Thereby the thickness of sediments in the west is reduced and in the east is increased. In effect plouton- 
ism of and position and influence of granite mass has brought near the surface, wide altrations in the region has caused, on the other hand created fragmentation and shifts in studied collection shows macroscopic samples display of granitoids area.

\section{Methods}

In this study, we have tried to field investigations, laboratory and compared to the previous preliminary research on the characteristics of lithology, mineralogy, geochemistry of mineralization and the deposit is to be surveyed. In this regard, after collecting data, field survey was carried out rock samples from different parts of ore (ore body, skarn and different parts of alteration, intrusive and volcanic rocks of the region) were taken 30 sample in order to prepare thin-polished sections and 30 samples for chemical analysis (XRF and ICP-MS) were selected.

\section{Mineralogy and Mineralography}

\subsection{Metallic Minerals}

-Magnetite: magnetite is the most original and most abundant minerals in the ore that along with hematite, chalcopyrite, pyrite and malachite, goethite and limonite is seen. The texture of magnetite in microscopic sections is massive and replacement. Dimensions magnetite crystals vary from 2.0 to $6 \mathrm{~mm}$. Sometimes crystals with dimensions of a few millimeters on all forms of manual are visible. In some outcrops, effects of tectonic pressures can be seen as a crunch. Much of magnetite lenses as a result of physical processes have become goethite. The presence of magnetite can be explained this way in two groups, the first group: For amorphous and spotted and it seems that the substitution phenomenon is shaped in the host rocks. In the examination of the depth of the mineralization remains relatively healthy but in samples of shallow in many cases oxidation and converted to hematite or are transformed. Hematitization often from the margins seeds or from within or from the center is beginning to fracture, causing martitic texture (Figure 3(a), Figure 3(b)). The second group magnetite which are massive texture the more in sectors that higher grade is visible. The dominant gangue minerals with this type of magnetites are amphibole, feldspar and silicate minerals.

-Hematite: Hematite frequency is lower than magnetite and economically in the region does not matter. The near-surface mineralization in areas or in areas with outcrops of magnetite and magnetite in fracture surfaces were found to be both primary and secondary. The amount of hematite is inversely proportional to the depth of the samples. Although hematite can melt under high oxygen fugacity iron oxides, but within the primary effects of hematite is rarely seen. It seems that almost all the ore hematite magnetite disruption caused by the conversion and most of the samples near the surface and exposed parts of the body can be seen. Other forms of hematite is formed during magnetite cleavage 

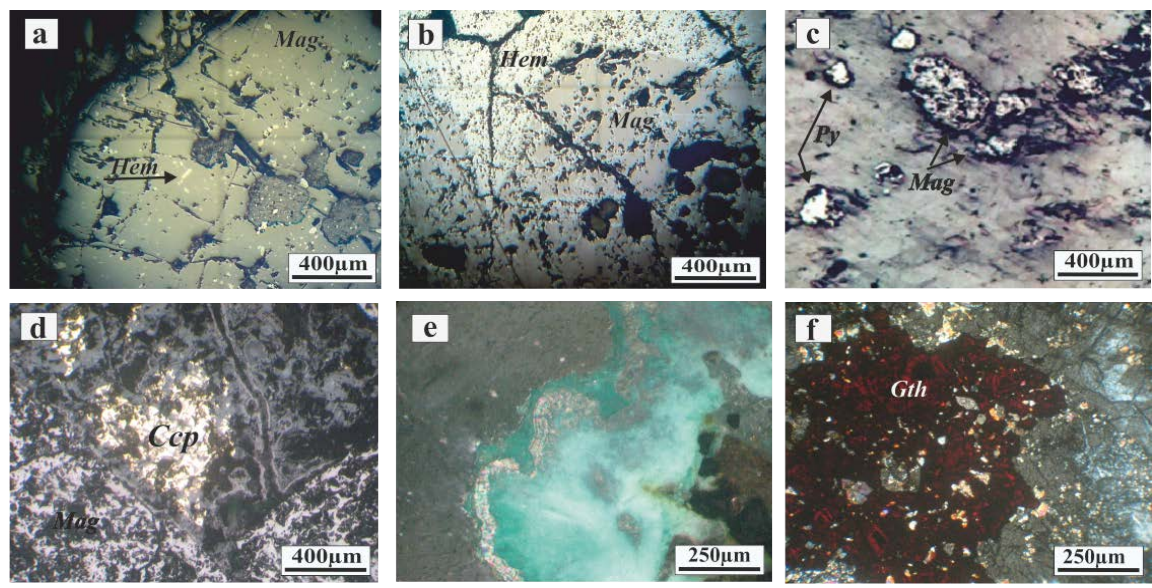

Figure 3. Microscopic images of metallic minerals formed in the Saheb deposit. (a) (b): Magnetite massive and the presence of hematite in magnetite. (c) (d): The mineral of pyrite and chalcopyrite in the Saheb skarn; (e): Malachite green vein in the colloidal texture in magnetite; (f): Goethite (iron hydroxide) in a sample of the orebody. Magnetite: Mag, hematite: Hem, pyrite: Py, chalcopyrite: Ccp, goethite: Gth, sphene: Spn [12].

surfaces. This texture is called as Martite, usually secondary and post-ore formation and the effect of temperature drop is created (Figure 3(a), Figure 3(b)).

-Pyrite: Pyrite is sulphide mineral that in some sections and macroscopic samples is visible (Figure $3(\mathrm{c})$ ). It seems that the pyrite in the ore with 1.0 to 3.0 $\mathrm{mm}$ dimensions and forms to amorphous hypidiomorphic to be seen. And is plasced in between magnetite and gangue minerals and usually the margins are becoming secondary hydroxides such as goethite.

-Chalcopyrite: Chalcopyrite is the most abundant sulphide mineral observed and in the area in the last stages of ore formation is formed. The microscopic sections, with dimensions of 0.2 to $0.4 \mathrm{~mm}$ can be seen (Figure 3(d)) and in the surface areas of the deposits have to be altered in copper minerals such as malachite.

-Malachite: Malachite with a size of 100 microns to more than a millimeter, ospace filling and fractures and associated magnetite is present in the form of thin strips and in the studied sections is seen for bright green color and shows colloform texture (Figure 3(e)).

-Goethite: goethite is an iron hydroxide mineral and in ore body fractures is abundance. The mineralization with colloform texture on microscopic sections manifested and it greatly decreases with increasing depth. The hematite is formed by dehydration of goethite (Figure 3(f)).

\subsection{Waste Minerals}

Garnet is one of the most silicate minerals observed in the area with massive magnetite. This mineral is most abundant non-metallic mineral in this area, including garnet isotropic and anisotropic. According mineralogy studies XRD [13] contains and radite and grossular. It has zonation and near the contact zone of garnet color change from brown to red to yellow in the distance it will change. 
Garnets in some cases more than $90 \%$ of the rock volume makes up a rock. Epidote group minerals (Epidote, Zoisite and Clinozoisite) in local outcrops are seen in green, after garnets are most abundant of sillicate minerals. Other non-metallic minerals observed in the region include: calcite, quartz, sphene, chlorite, amphibole (actinolite-tremolite series) (Figure 4).

\section{Discussion}

\section{Mineralization}

Iron mineralization in Saheb area in the limestone units as replacement, joint fillers and fractures of dissolution as individual lenses, in the same trend has taken place. According to most $\mathrm{Fe}-\mathrm{Cu}$ skarn mineralization in this area are as lens, with outcrops at surface and in a trending east-west length of $2 \mathrm{~km}$ (and more) and with a thickness of up to 25 meters, although numerous amputation (on the surface) are visible. Lens length varies from 3 to $100 \mathrm{~m}$ and its thickness from a few centimeters to a few meters and sometimes "a few tens of meters change. The lens is placed in the center of the area, in particular iron oxides, magnetite is often included [9]. Mineral outcrops in some areas in parallel are 2 to 3 times. Outcrop of vein malachite can be seen in the vicinity of magnetite body (Figure 5(e)). The slope of ore body in most cases is high and close to the vertical and mostly to the south. The ore is concentrated mainly in the form of magnetite and textures observed in the ore, massive, disseminated and replacement, flooring, space filling texture and the sometimes cataclastic (Figure 5(a), Figure 5(b)). So we can say that the Saheb iron deposit mineralogy consists of metallic minerals: magnetite, hematite, geothite, malachite (Figure 5(d)), chalcopyrite, pyrite and with significant phases such as epidotization (Figure 5(c)), chloritization, and kaolinitization has been associated. It seems that during the skarn and under the conditions prevailing oxygen fugacity, ore body as prevail oxide
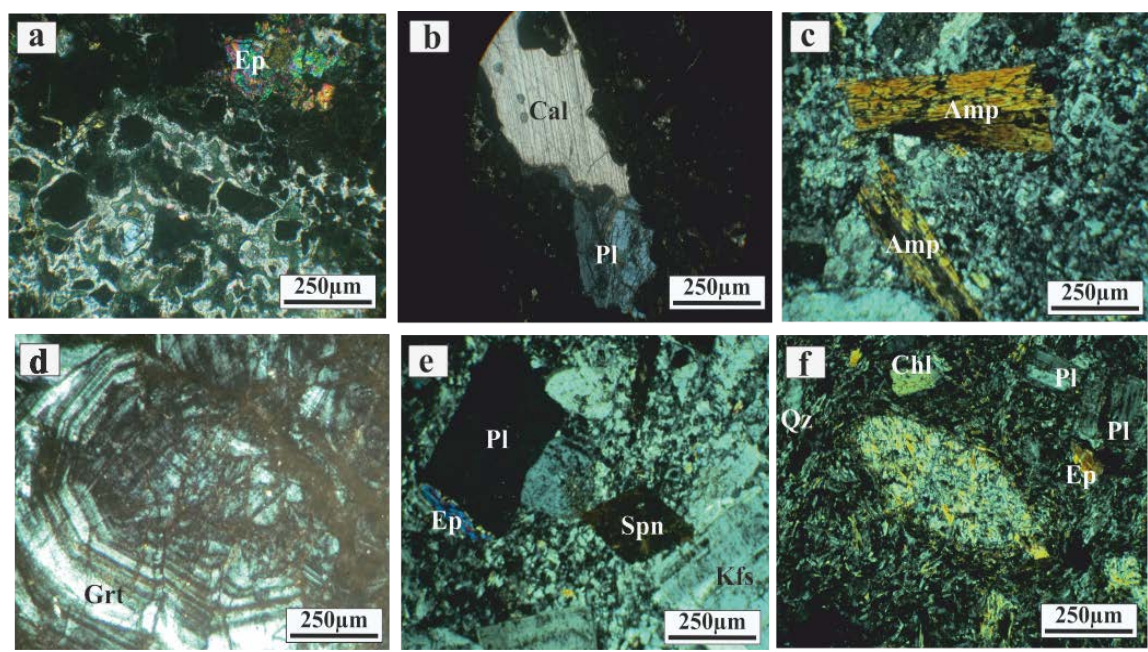

Figure 4. Microscopic images of non-metallic minerals observed in Saheb skarn. This minerals are: Garnet: Grt, chlorite: Chl, Amphibole: Amp, Plagioclase: Pl, Qartz: Qz, epidote: Ep, Calcite: Cal, Kfs: K-feldspar [12]. 

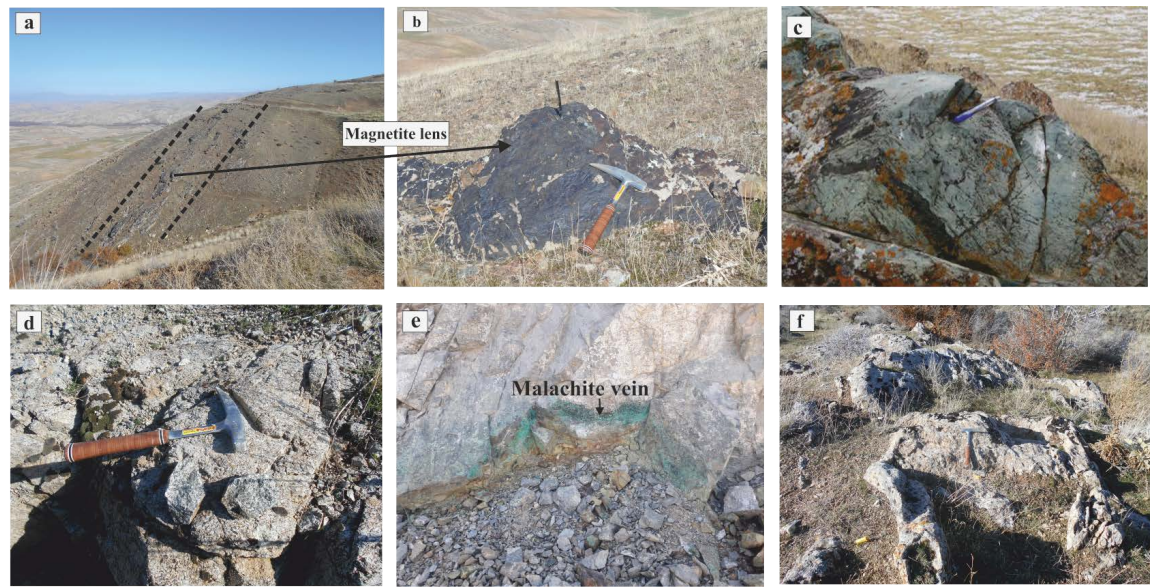

Figure 5. Macroscopic images of outcrop of lithologiic different units of the Saheb deposit; (a) (b) Outcrops of magnetite lenses (sight east); (c) Epidotization observed in rock units; (d) Outcrop of intrusive body in Saheb skarn; (e) Outcrop of malachite in area; (f) View of the units skarnization in the Saheb skarn.

phase in the region, is performed. Low frequency sulfide phases in samples that were collected from the surface, due to the increase in low sulfur fugacity in the next step. Iron ore consists of two parts or hypogene ore (oxide and sulfide) and supergene ore [9].

In the formation of very skarn in which mineralization occurred and metasomatism process caused skarn formation, one or two steps, prograde altration and depending on the type and number of secondary minerals one or two steps, retrograde altration occur. Based on field evidence and microscopic studies of the skarn zone, skarnization process (Figure 5(f)) in Saheb area occurs in two main stage: 1-prograde altration 2-retrograde alteration.

In this area, mineralization in both oxide and sulfide forms and after the formation of initial anhydrous calc silicates and during subsequent changes occur [14] [15]. In Saheb skarn magnetite is the first metal ore deposited (Figure 3(a), Figure $3(\mathrm{~b})$ ). Hematite is mainly due to the conversion of magnetite (Figure $3(\mathrm{a})$, Figure 3(b)). Geothite is a productive of magnetite and hematite weathering that has been converted to geothite by meteoric waters (Figure 3(f)). $\mathrm{Fe}_{2} \mathrm{O}_{3}$ (magnetite) $+\mathrm{H}_{2} \mathrm{O}=2 \mathrm{FeO}(\mathrm{OH})$ goethite.

Pyrite and calcopyrite are from sulfide ore minerals in Saheb deposite at the retrograde stage (Figure 3(c)). According to [16] calcopyrite due to the increase of $\mathrm{pH}$ and $\mathrm{fO}_{2}$ decrease (Figure 3(d)), formed according with the following reaction:

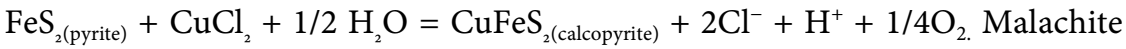
is formed by supergene process of Saheb ore, meteoric fluids rotation and altration of calcopyrite. (Figure 3(e)).

\section{Paragenesis}

Based on mineralogy, mineralography studied Paragenetic sequence can be 
summarized in for steps. 1) Influence of the granitoid intrusive body; 2) Applying contact metamorphism and skarnization; 3) prograde and retrograde alteration; 4) Deposited in carbonate rocks. In the stages of prograde altration, garnet and pyroxene are formed and in the retrograde altration, due to lower temperature and the possible influence of meteoric waters, hydrous minerals such as epidote and tremolite-actinolite due to altration of the previous stage minerals are formed. Magnetite is formed at the end of the stages of Prograde or in the beginning of the stage. Sulfid minerals are formed in the end of formation deposit (Table 1).

\section{Geochemistry of Ore Deposits}

In the formation of mineral deposits, many factors are effective, and the role of these factors in the type of deposit, alteration and geochemical characteristics are reflected. Analysis of XRF and ICP-MS (samples taken from trenches and surface samples) in Table 2 and Table 3 is provided and the behavior of various elements in rock samples (intrusion body) is checked. In According to [17] intrusive body chemical composition is placed mainly of granite, granodiorite-diorite and (Figure 6, Figure 5(d)). Based on the [18] and [19] [20] granitoids in this area are belonged to series of sub-alkaline with rich potassium and are metaluminous. On the other hand, due to the presence of hornblende, granitoids area, the $\mathrm{Na}$ content higher than $2.3 \%$, the presence of pyroxene series

Table 1. Paragenetic sequence in the Saheb skarn.

\begin{tabular}{|c|c|c|c|}
\hline \multicolumn{4}{|c|}{ Paragenetic sequence } \\
\hline \multirow{2}{*}{ Minerals } & Metas & Altration & \multirow{2}{*}{ Supergene altration } \\
\hline & Prograde stage & Retrograde stage & \\
\hline \multicolumn{4}{|l|}{ Magnetite } \\
\hline \multicolumn{4}{|l|}{ Hematite } \\
\hline \multicolumn{4}{|l|}{ Martite } \\
\hline \multicolumn{4}{|l|}{ Pyrite } \\
\hline \multicolumn{4}{|l|}{ Chalco-Pyrite } \\
\hline \multicolumn{4}{|l|}{ Geothite } \\
\hline \multicolumn{4}{|l|}{ Malachite } \\
\hline \multicolumn{4}{|l|}{ Garnet } \\
\hline \multicolumn{4}{|l|}{ Diopside } \\
\hline \multicolumn{4}{|l|}{ Quartz } \\
\hline \multicolumn{4}{|l|}{ Calcite/ } \\
\hline \multicolumn{4}{|l|}{ Dolomite } \\
\hline \multicolumn{4}{|l|}{ Amphibole } \\
\hline \multicolumn{4}{|l|}{ Epidote } \\
\hline Cholorite & & & \\
\hline
\end{tabular}


Table 2. Results of the analysis of samples of surface (oxide major and minor elements of intrusion body) in Saheb deposite (North West of Iran) by XRF.

\begin{tabular}{ccccccccccccc}
\hline Sample. & $\mathrm{SiO}_{2}$ & $\mathrm{Al}_{2} \mathrm{O}_{3}$ & $\mathrm{Fe}_{2} \mathrm{O}_{3}$ & $\mathrm{CaO}$ & $\mathrm{Na}_{2} \mathrm{O}$ & $\mathrm{K}_{2} \mathrm{O}$ & $\mathrm{MgO}$ & $\mathrm{TiO}_{2}$ & $\mathrm{MnO}$ & $\mathrm{P}_{2} \mathrm{O}_{5}$ & L.O.I & Total \\
\hline Code & $\%$ & $\%$ & $\%$ & $\%$ & $\%$ & $\%$ & $\%$ & $\%$ & $\%$ & $\%$ & $\%$ & $\%$ \\
S.2.P & 70.5 & 14.6 & 2.21 & 2.14 & 4.8 & 3.02 & 1.02 & 0.34 & 0.07 & 0.1 & 1.81 & 99.59 \\
S.22.P & 59.03 & 12.82 & 8.95 & 2.09 & 1.03 & 1.01 & 7.12 & 1.596 & 0.177 & 1.155 & 1.56 & 95.51 \\
S.38.P & 67.92 & 12.87 & 3.58 & 2.78 & 2.21 & 1.07 & 4.65 & 1.092 & 0.149 & 0.217 & 3.07 & 99.60 \\
S.10.P & 65.96 & 14.93 & 5.98 & 2.32 & 0.31 & 1.08 & 4.68 & 1.099 & 0.158 & 0.312 & 2.14 & 98.96 \\
S.11.P & 56.41 & 14.07 & 6.24 & 5.35 & 3.52 & 2.81 & 4.5 & 1.012 & 0.054 & 0.602 & 0.25 & 94.81 \\
S.7.1.P & 65.49 & 14.92 & 3.05 & 2.01 & 4.69 & 2.78 & 2.83 & 0.412 & 0.038 & 0.148 & 1.91 & 98.28 \\
S.34.P & 62.43 & 13.96 & 4.25 & 3.01 & 4.75 & 2.65 & 3.13 & 0.513 & 0.065 & 0.159 & 1.33 & 96.24 \\
S.30.P & 73.69 & 12.08 & 1.85 & 0.81 & 2.92 & 4.38 & 0.85 & 0.301 & 0.014 & 0.091 & 2.26 & 99.25 \\
S.29.P & 58.30 & 14.31 & 6.18 & 4.19 & 4.95 & 3.58 & 3.19 & 0.509 & 0.068 & 0.476 & 1.73 & 96.50 \\
S.76.P & 65.78 & 16.12 & 1.55 & 3.41 & 5.53 & 3.91 & 1.9 & 0.53 & 0.05 & 0.39 & 0.92 & 100.11 \\
\hline
\end{tabular}

Table 3. Analysis of trace and rare elements examples intrusive body in Saheb deposite (North West of Iran) by ICP-MS.

\begin{tabular}{|c|c|c|c|c|c|c|c|c|}
\hline \multirow{2}{*}{$\begin{array}{l}\text { Sample } \\
\text { Code }\end{array}$} & \multirow{2}{*}{$\frac{\mathrm{Ni}}{(\mathrm{ppm})}$} & \multirow{2}{*}{$\mathrm{Rb}(\mathrm{ppm})$} & \multirow{2}{*}{$\frac{\mathrm{U}}{(\mathrm{ppm})}$} & \multirow{2}{*}{$\frac{\mathrm{V}}{(\mathrm{ppm})}$} & \multirow{2}{*}{$-\mathrm{Nb}(\mathrm{ppm})$} & \multirow{2}{*}{$\frac{\mathrm{Y}}{(\mathrm{ppm})}$} & \multirow{2}{*}{$\begin{array}{c}\text { Co } \\
\text { (ppm) }\end{array}$} & \multirow{2}{*}{$\frac{\mathrm{Cr}}{(\mathrm{ppm})}$} \\
\hline & & & & & & & & \\
\hline S.2.P & 29 & 4 & 7.1 & 40 & 3.7 & 12.6 & 9 & 44 \\
\hline S.22.P & 36 & 49 & 3.1 & 76 & 5 & 3.2 & 10 & 49 \\
\hline S.38.P & 18 & 2 & 1.2 & 11 & 1.7 & 5.3 & 12 & 18 \\
\hline S.10.P & 19 & 4 & 2.4 & 51 & 1.8 & 12.9 & 13 & 42 \\
\hline S.11.P & 28 & 47 & 3.3 & 80 & 22 & 11.3 & 15 & 50 \\
\hline S.7.1.P & 14 & 98 & 2.9 & 41 & 6.8 & 6.2 & 4 & 33 \\
\hline S.34.P & 23 & 10 & 4.3 & 53 & 10.9 & 15.9 & 9 & 81 \\
\hline S.30.P & 20 & 62 & 2.4 & 78 & 21.7 & 13.9 & 23 & 145 \\
\hline S.29.P & 39 & 28 & 3.7 & 48 & 6.3 & 13.1 & 10 & 38 \\
\hline S.76.P & 31 & 66 & 2.3 & 54 & $<1$ & 13 & 16 & 16 \\
\hline Ab.1 & 41 & 35 & 2.8 & 26 & 18 & 2.1 & 37 & 14 \\
\hline Ab. 2 & 30 & 31 & 3.9 & 45 & 32 & 14 & 11 & 36 \\
\hline Ab. 3 & 16 & 53 & 4.7 & 52 & 31 & 19 & 16 & 59 \\
\hline $\mathrm{Ab} .4$ & 31 & 55 & 2.3 & 54 & 22 & 28 & 11 & 15 \\
\hline
\end{tabular}

diopside [9], sphene and magnetite presence [21] and the charts [18] [19] [20] [21] Saheb intrusion body is belong to subalkaline, metaluminus, I-type category of granites and high-k calalkaline, (Figure 7) and based on [22] [23] it belong to tectomagmatic environment of continental margins subduction zone and VAG (Figure 8). 


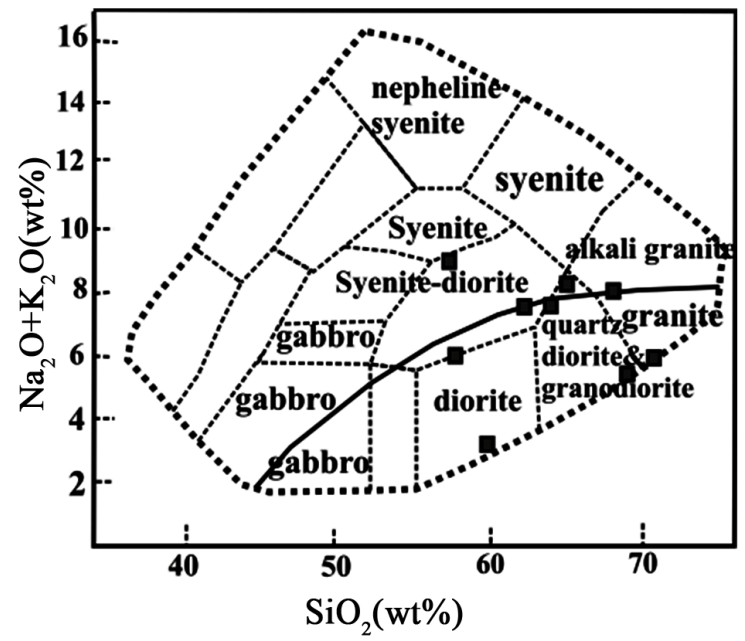

Figure 6. The Chemical classification of intrusive rocks based on the A: [17].

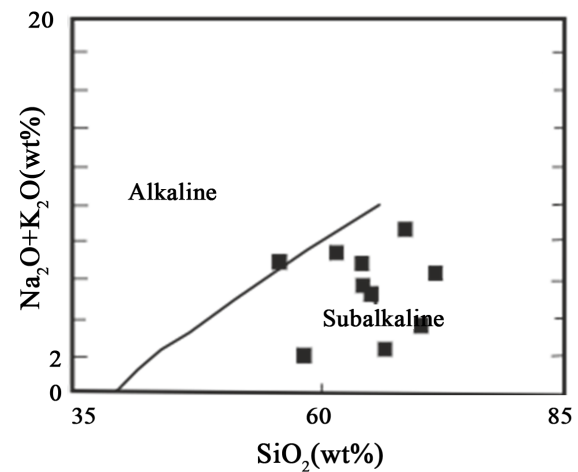

(a)

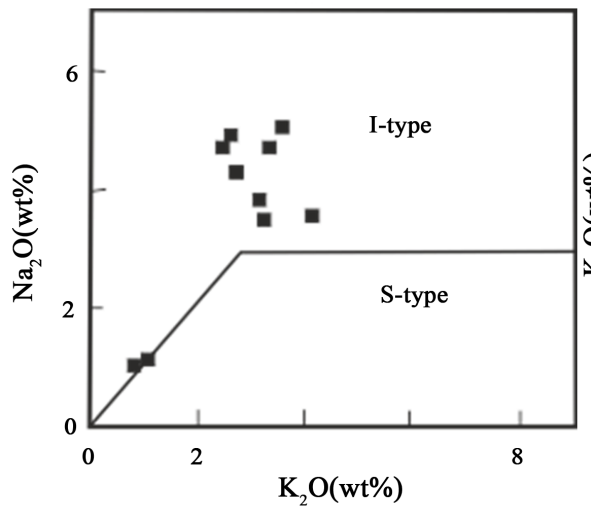

(c)

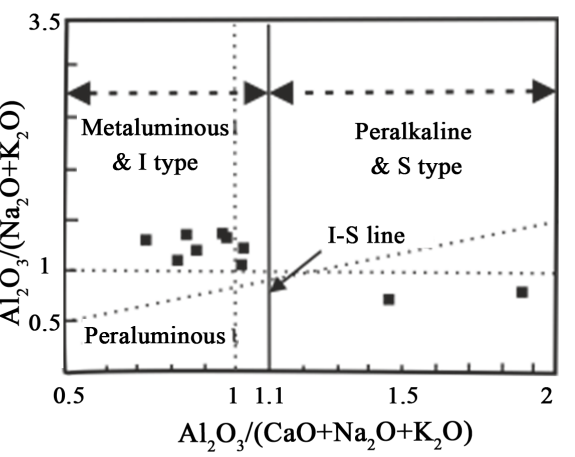

(b)

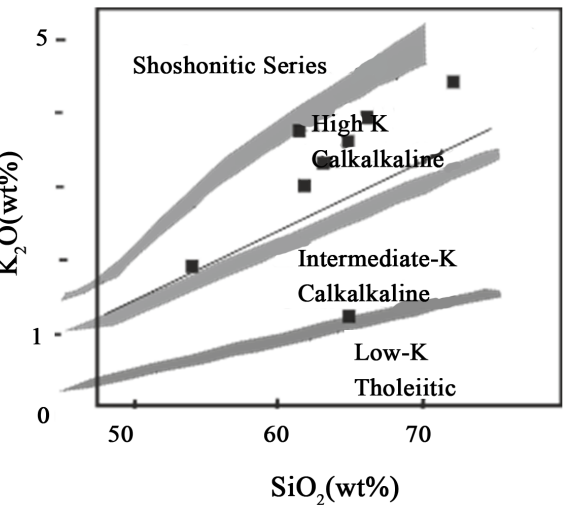

(d)

Figure 7. (a) Series magmatic diagram and placements within sub-alkaline magmatic [18]; (b) Metaluminous and peraluminous Separated chart, intrusive and volcanic rocks are metaluminous; [19]; (c) Type of granitoids in the area are I-type [20]; (d) The rock samples belong to high potassium calc-alkaline [21].

According to [24] studies, content $\mathrm{MgO}, \mathrm{K}_{2} \mathrm{O}$ and $\left(\mathrm{Na}_{2} \mathrm{O}+\mathrm{K}_{2} \mathrm{O}\right)$ versus $\mathrm{SiO}_{2}$, show the most important distinction between $\mathrm{Fe}, \mathrm{Cu}, \mathrm{Au}, \mathrm{W}$, Mo skarn granitoid. The chemical composition and geological data means intrusion body on the 


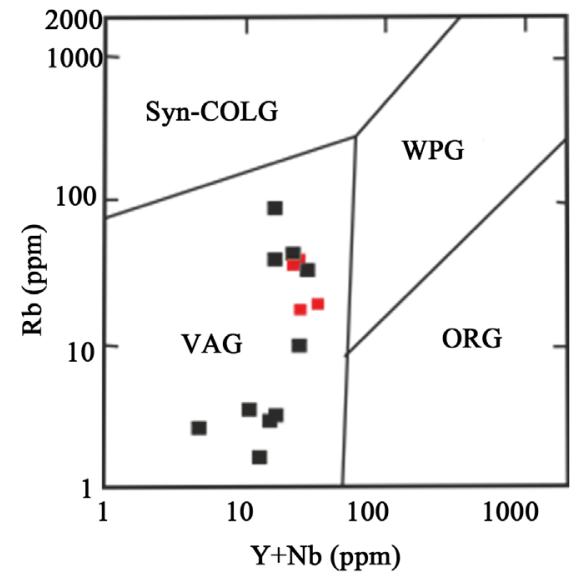

(a)

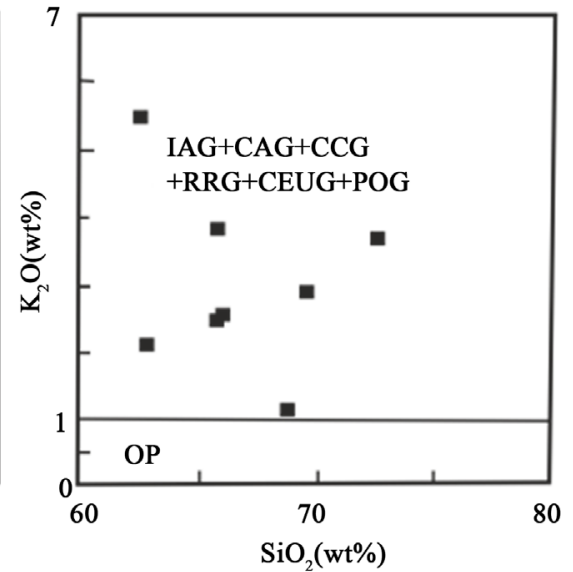

(b)

Figure 8. Tectonical setting of Saheb granitoids and belong to volcanic Arc Granitoids [22]. Red samples [23].

charts (Figure 9) is drawn. Fe skarn granitoids compared to other skarns have higher $\mathrm{MgO}, \mathrm{K}_{2} \mathrm{O}$ and $\mathrm{SiO}_{2}$ less. Average $\mathrm{K}_{2} \mathrm{O}$ iron skarn granitoids, copper and gold respectively $2.1 \% 3.6 \%$ and $2.5 \%$ have been reported [25]. Average $\mathrm{K}_{2} \mathrm{O}$ of Saheb granitoid is $14.11 \%$ and close to the average Fe skarns. In the dispersion pattern of data in the $\mathrm{K}_{2} \mathrm{O}$ versus $\mathrm{SiO}_{2}$ chart, it is close to $\mathrm{Fe}$ and $\mathrm{Fe}-\mathrm{Cu}$ skarns (Figure 9(a)). Therefore given that of skarn samples are near the $\mathrm{Au}-\mathrm{Cu}$ average, Saheb skarnis important Au potential also. The average $\mathrm{MgO}, \mathrm{Fe}, \mathrm{Au}$ and $\mathrm{Cu}$ skarn granitoids respectively about $3 \%, 3.2 \%$ and $1.8 \%$ [25]. Average $\mathrm{MgO}$ intrusion owner equal to $2.95 \%$ and it is close to Fe skarn (Figure 9 (b)). The dispersion pattern of Granitoids in the chart $\mathrm{MgO}$ versus $\mathrm{SiO}_{2}$ also the highest distribution shows around of $\mathrm{Cu}-\mathrm{Fe}$ and $\mathrm{Au}-\mathrm{Cu}$ skarns. So we can say that granitoids of this region can be associated with $\mathrm{Cu}-\mathrm{Fe}$ skarns or $\mathrm{Cu}-\mathrm{Au}$. In the diagram of total alkali $\left(\mathrm{Na}_{2} \mathrm{O}+\mathrm{K}_{2} \mathrm{O}\right)$ versus $\mathrm{SiO}_{2}$, scattering Saheb samples places around $\mathrm{Fe}$ and $\mathrm{Cu}-\mathrm{Fe}$ skarns. Average $\left(\mathrm{Na}_{2} \mathrm{O}+\mathrm{K}_{2} \mathrm{O}\right)$ of the Saheb samples is $1.5 \%$ and is comparable to Au skarn (Figure 9(c)). Average total alkaline in $\mathrm{Cu}$, $\mathrm{Fe}$ and $\mathrm{Au}$ skarns, is respectively 7.6\%, 6.1\% and 5.6\% [25]. The ratio of $\mathrm{Mg} / \mathrm{K}_{2} \mathrm{O}$ skarn granitoids can be used to detect skarn type. This raio for for $\mathrm{Fe}, \mathrm{Cu}$ and $\mathrm{Au}$, respectively is, 2, 2.9 and 1 [25], and for Saheb granitoid approximately 0.7 and is very close to granitoids the Au skarn. Average $\mathrm{V}$ and $\mathrm{Ni}$, respectively in $\mathrm{Fe}$ skarn is $152 \mathrm{ppm}, 35 \mathrm{ppm}, \mathrm{Cu}$ is $85 \mathrm{ppm}, 16$ and the Au skarn are 99 ppm, 18 ppm [25]. The mean values of $\mathrm{V}$ and $\mathrm{Ni}$ in the Saheb samples are about $58 \mathrm{ppm}$, $21 \mathrm{ppm}$, and from this point of view are close to the $\mathrm{Cu}$ and Au skarns (Figure $9(d))$.

\section{Conclusions}

Recent research shows, carbonate rocks in the Saheb region have been acting as iron skarn protolite rocks. During oligomiocene, magmatic transformation causes infiltration of Saheb granitoid body and consequently contacts with the Permian carbonate rocks. Heat of intrusive body creates the background for the 


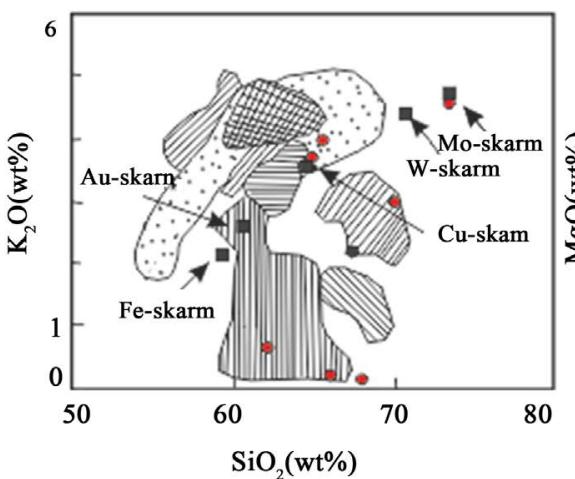

(a)

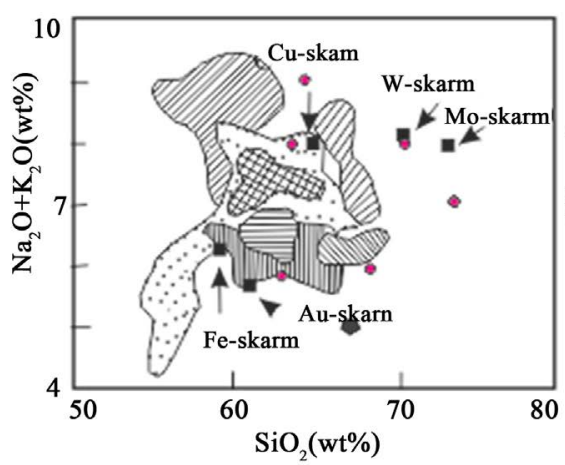

(c)

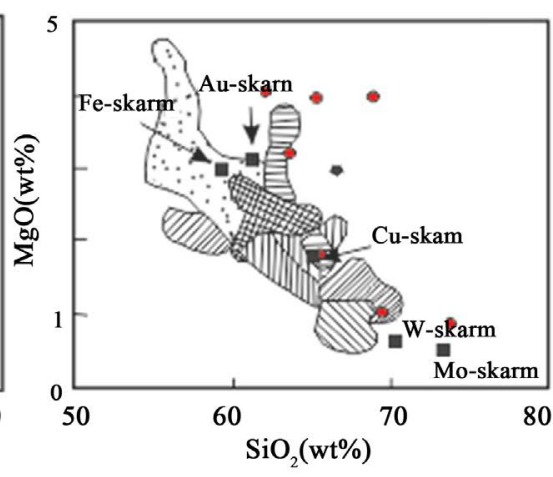

(b)

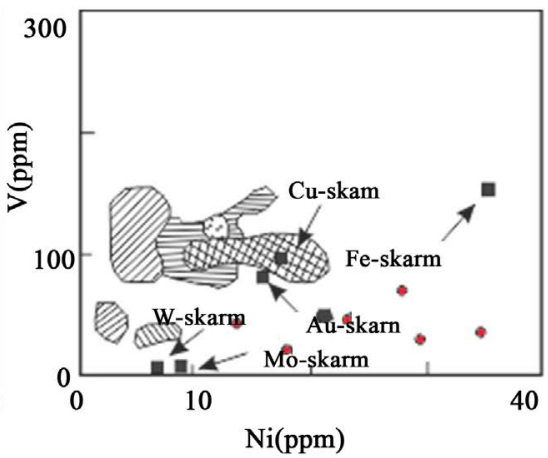

(d)

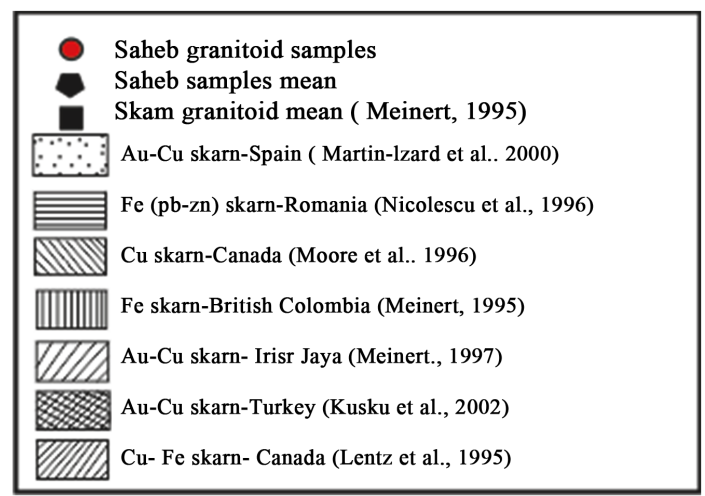

Figure 9. Comparison of Saheb skarn productive granitoids with the world's great skarn granitoids [24].

action of hydrothermal solutions and the formation of skarn. Saheb skarn is divided into two parts: The Endo skarn and skarn exoskarns. Endo-skarn zone is less than exoskarns. Exoskarn is divided into two zones of garnet and epidote skarn. Much of the ore-bearing zone is concentrated in garnet skarn. Based on petrographic studies, mineralogy, altration and mineralization, two-step retrograde altration is detectable in the region. Mineralization in the district is divided into two types: the primitive type and skarn type.

Magnetite is the most important and most abundant oxid minerals of the region. According to chemical analysis tests, the combination of plutonic body of Saheb is granite and granodiorite-diorite, metaluminous, calkalcaline (rich in potassium), I type, tectonically belongs to VAG (Granitoid Arc Volcanic) and is 
similar to other $\mathrm{Fe}, \mathrm{Cu}, \mathrm{Fe}-\mathrm{Cu}, \mathrm{Cu}-\mathrm{Au}$ skarn forming granitoids worldwide in the terms of mineralization potentials.

\section{References}

[1] Golmohammadi, A., Karimpour, M.H., Malekzadeh Shafaroudi, A. and Mazaheri, S.A. (2015) Alteration-Mineralization, and Radiometric Ages of the Source Pluton at the Sangan Iron Skarn Deposit, Northeastern Iran. Ore Geology Reviews, 65, 545-563. https://doi.org/10.1016/j.oregeorev.2014.07.005

[2] Nabatian, Gh., Rastad, E., Neubauer, F., Honarmand, M. and Ghaderi, M. (2015) Iron and Fe-Mn Mineralization in Iran: Implication for Tethyan Metallogeny. Australian Journal of Earth Science, 62, 211-241.

https://doi.org/10.1080/08120099.2015.1002001

[3] Baghban, S., Hosseinzadeh, M.R., Moayyed, M., Mokhtari, M.A.A. and Gregory, D. (2015) Geology, Mineral Chemistry and Formation Conditions of Calc-Silicate Minerals of Astamal Fe-LREE Distal Skarn Deposit, Eastern Azarbaijan Province, NW Iran. Ore Geology Reviews, 68, 79-96.

https://doi.org/10.1016/j.oregeorev.2014.12.016

[4] Baghban, S., Hosseinzadeh, M.R., Moayyed, M., Mokhtari, M.A.A., Gregory, D.D. and Mahmoudi Nia, H. (2016) Chemical Composition and Evolution of the Garnets in the Astamal Fe-LREE Distal Skarn Deposit, Qara-Dagh-Sabalan Metallogenic Belt, Lesser Caucasus, NW Iran. Ore Geology Reviews, 78, 166-175. https://doi.org/10.1016/j.oregeorev.2016.02.020

[5] Vahid, A. (2013) Comparative Review of the Northern Sanandaj-Sirjan Zone Granitoids. Journal of Tethys, 1, 128-137.

[6] Mansour, G. (2013) The Economic Geology of Iran, Mineral Deposits and Natural Resources. Springer Geology, Berlin, 542 p.

[7] Rahimi, H. (2011) Genetic Characteristics and Mineralogy of Iron Deposits of Sanandaj-Sirjan and Its Relation to the Magnetic Field. Master's Thesis, University of Yazd (Iran).

[8] Fattah, H.A. (2001) Report of Gold and Iron Exploration Plan in Saheb Copper-Iron Deposit: Geological Survey and Mineral Exploration of Iran, 181 p.

[9] Zandi, Z. (2017) Mineralization, Geochemistry and Genesis of Saheb Fe-Cu Skarn, North West of Kurdistan Province, NW Iran (Saqqez). Ph.D. Thesis, Economic Geology Dept. Science and Research University, Iran, $226 \mathrm{p}$.

[10] Aghanabati, S.A. (2004) Geology of Iran. Publishing: Geological Survey and Mineral Exploration of Iran, $606 \mathrm{p}$.

[11] Soheili, M., Bani Adam, F. and Hesami, A.F. (2001) Geological Map, 1:5000 of Saheb, Geological Survey and Mineral Exploration of Iran and Earth Sciences Development Company.

[12] Whitney, D.L. and Evans, B.W. (2010) Abbreviations for Names of Rock-Forming Minerals. American Mineralogist, 95, 185-187. https://doi.org/10.2138/am.2010.3371

[13] Nasim, A. (2007) Reviews Iron Ore Reserve of the Saheb Iron Deposit in Saqqez City. Master's Thesis. Shahid Beheshti University, University of Geosciences, Iran, $107 \mathrm{p}$.

[14] Einaudi, M.T. (1982) Descriptions of Skarn Associated with Porphyry Copper Plutons, Southwestern North America. In: Titley, S.R., Ed., Advances in Geology of the Porphyry Copper Deposits, Southwestern North America: Tucson, University of 
Arizona Press, 239-284.

[15] Meinert, L.D. (1997) Application of Skarn Deposit Zonation Models to Mineral Exploration. Exploration and Mining Geology, 6, 185-208.

[16] Zotov, A.V., Kudrine, A.V., Levine, K.A., Shikina, N.D. and Varyash, L.N. (1995) Experimental Studies of the Solubility and Complexing of Selected Ore Elements $(\mathrm{Au}, \mathrm{Ag}, \mathrm{Cu}, \mathrm{Mo}, \mathrm{As}, \mathrm{Sb}, \mathrm{Hg})$ in Aqueous Solution. Chapman and Hall, London, $323 \mathrm{p}$.

[17] Cox, K.G., Bell, J.D. and Pankhurst, R.J. (1979) The Interpretation of Igneous Rocks. George Allen and Unwin, London.

[18] Irvine, T.N. and Baragar, W.R.A. (1971) A Guide to the Chemical Classification of the Common Volcanic Rocks. Canadian Journal of Earth Sciences, 8, 523-548. https://doi.org/10.1139/e71-055

[19] Maniar, P.O. and Piccolli, P.M. (1989) Tectonic Discrimination of Granitoids. Geological Society of American Bulletin, 101, 635-643.

[20] Chappell, B.W. and White, A.J.R. (2001) Two Contrasting Granite Type: 25 Years Later. Australian Journal of Earth Science, No. 48, 489-499.

[21] Le Maitre, R.W. (1989) A Classification of Igneous Rocks and Glossary of Terms. Blackwall, Oxford.

[22] Pearce, J.A., Harris, N.B. and Tindle, A.G. (1984) Trace Element Discrimination Diagrams for the Tectonic Interpretation of Granitic Rocks. Journal of Petrology, 25, 956-983. https://doi.org/10.1093/petrology/25.4.956

[23] Dana, K. (2008) Examination of Geology, Mineralogy and Geochemistry of Saheb Deposit (East Saqqar-Kurdistan). Master's Thesis, Faculty of Natural Sciences, University of Tabriz, Tabriz.

[24] Kuscu, I., Genc, A.K.G., Meinert, L. and Floyed, P.A. (2002) Tectonic Setting and Petrogenesis of Celebi Granitoid, (Kirikale-Turkey) and Comparison with World Skarn Granitoids. Journal of Geochemical Exploration, 76, 175-194. https://doi.org/10.1016/S0375-6742(02)00254-6

[25] Meinert, L.D. (1995) Compositional Variation of Igneous Rocks Associated with Skarn Deposits-Chemical Evidence for a Genetic Connection between Petrogenesis and Mineralization. Mineralogical Association of Canada, Short Course Series 23, 401-418. 